\title{
音楽提示による「わくわく感」を利用した覚醒水準の低下の防止 一脳波と眼球運動を利用して一
}

○伊藤 弘大、原田 圭裕（芝浦工業大学大学院理工学研究科）

谷 友貴、長谷川 裕也、大倉典子 (芝浦工業大学工学部)

中辻 晴彦、舘 陽介、瀬戸 洋紀 (アルパイン (株))

相川 健（(株）ユニテック） 中山 記男（(合）オラニエ)

Prevention of decrease of arousal level by the music presentation using exciting feeling

-Analysis using EEG and eye movement-

Kodai ITO, Yoshihiro HARADA, Tomoki TANI, Yuya HASEGAWA, Michiko OHKURA

(Shibaura Institute of Technology),

Haruhiko NAKATSUJI, Yousuke TATE, Hironori SETO (Alpine Electronics, Inc.),

Ken AIKAWA (UNITEC Co., Ltd.), Norio NAKAYAMA (Oranje LLC.)

\section{1.はじめに}

自動車の運転手が、運転以外一意識が向いてい る状態をドライバーディストラクションという1)。 その中には、睡眠不足による覚醒水準の低下が原 因と考えられる事故が多くある。この問題に対し て、「わくわく感」が覚醒水準の低下の防止に繫 がるのではないかと考えた。先行研究では「わく わく感」に関する研究を行い、一般的な場面にお ける若者にとっての「わくわく感」を定義した2)。 そこで、ドライビングシミュレータ (以下D. S) を用いてわくわくするコンテンツを作成し、「わ くわく感」が覚醒水準の低下の防止に繋がるかど うかを明らかにする実験を行った。なお本実験は、 本学生命工学倫理審査委員会の承認を得ている。

\section{2. 実験}

\section{1 実験内容}

先行研究と予備実験で得た知見に基づいてD.S 用コンテンツを作成し、「わくわく感」が覚醒水 準の低下の防止に有効であるかを評価することを 目的として実験を行った。眓1に実験システムの 構成を示す。

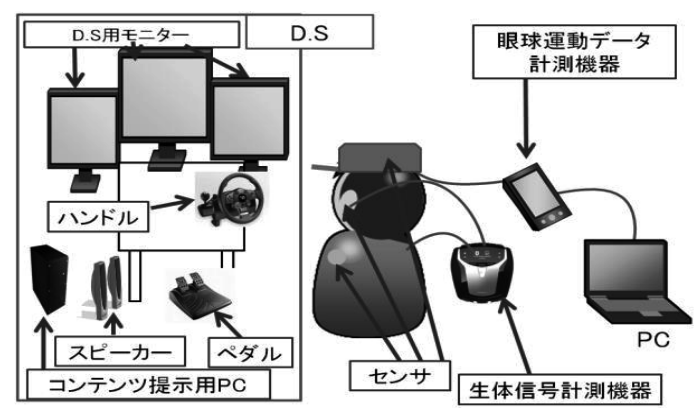

図1 システム構成図
ディスプレイの輝度の変化を少なくするため、 D.S コースは主にトンネルで構成し、一本道で、 後述する区間(1)が4か所、区間(2)が3か所ある。図 2にコース全体図を示す。本報では区間(2)の結果 を報告する。

・区間1)(トンネル区間)：トンネル内を走行し、 通過後に桜または紅葉の風景が見える区間。ただ し、風景がない場合も含む。各風景で 2 回ずつ走 行し、そのうち 1 回は事前にトンネル内でトンネ 儿通過後に見える風景について、事前に音声情報 を提示した。

・ 区間(2)(音楽提示区間)：トンネル内を走行中に、 音楽が流れる区間。事前に実験協力者に、自分が わくわくするボーカル曲を回答してもらい、その 中から 3 曲を選び、音楽提示区間 3 か所それぞれ で 90 秒間提示した。またこれまでの実験結果か ら、D.S の運転中、若者は自分がわくわくする音 楽を聴くとわくわくするが、サビの音量が上がる とわくわく感がさらに上がることがわかっている 2)。そこで、音楽の提示では、サビの時の音量が 上がるようにした。

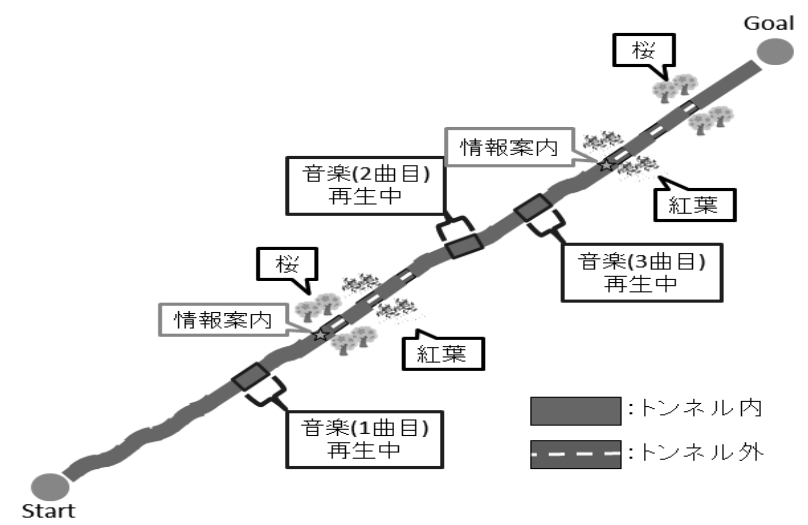

図2 コース全体図 
評価方法を以下に示す。

(1) アンケート

実験協力者にコース図上でわくわくした場所・ 眠くなった場所を回答してもらった。

（2）生体信号と生理指標

先行研究 2) 3) 4) より以下の生理指標で「わくわ

く感」と覚醒度を評価した。

・脳波 : $\beta / \alpha$ の平均值

• 心電 : SDNN : RRI の標準偏差、RRV : RRI の 標準偏差と RRI の平均の比

・眼球運動データ : 単位時間当たりの瞬目回数

\section{2 実験結果と考察}

実験は本学の 20 歳以上の男子学生10名を対象 に実施した。各生理指標は、以下の解析区間ご とに算出し、実験協力者ごとに「音楽提示前

(音楽が再生される前10秒間)」と差分をとって 基準化した。

・サビ開始前（サビが再生される前10秒間）

・サビ開始後（サビの始め10秒間）

・音楽提示後（音楽の再生停止後10秒間）

アンケートでは、ほとんどの実験協力者が、 音楽提示があった時にわくわくしたと回答した。

図3に1回目の $\beta / \alpha$ を示す。アンケートで音楽 提示区間の1回目で「わくわくした」と回答した 8 名を対象に解析を行った。脳波の $\beta / \alpha$ の平均值 および心電のSDNNとRRVの解析結果から、「サ ビ開始後」の值が「サビ開始前」より大きい有 意傾向があった $(\mathrm{p}<0.10)$ 。これらの值は、音楽 提示前と差分を取っているため、サビ開始後の 值は音楽提示前と比べても大きかったことがわ かる。このことから、音楽提示のサビ部分で実 験協力者がわくわくした可能性があるといえる。

図4に1回目の単位時間あたりの瞬目回数を示 す。正しく計測できなかった3名のデータを除外 し、正しく計測できた実験協力者7名のうち、

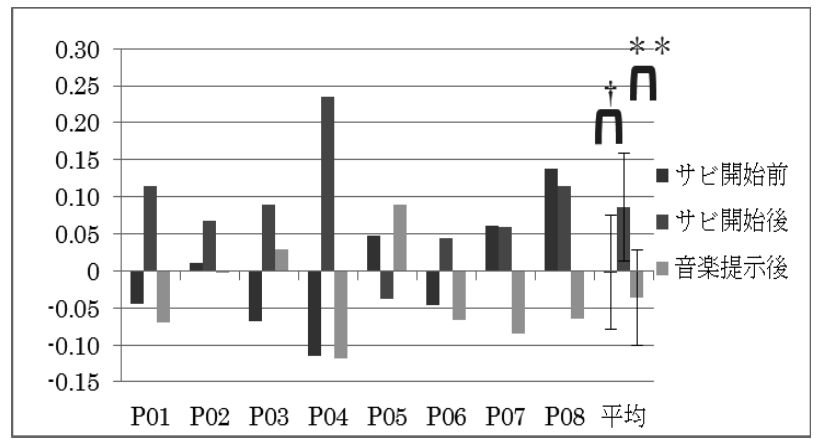

図3 音楽提示区間の1回目の $\beta / \alpha$
アンケートで音楽提示区間の1回目で「わくわく した」と回答した5名全員の「音楽提示後」の值 が、それ以前の「サビ開始前」や「サビ開始 後」と比べて小さかった。このことから、実験 協力者は音楽提示後に覚醒水準が上がったと考 えられる。



\section{図4音楽提示区間の1回目の単位時間あたり} の瞬目回数

\section{3. 結論}

先行研究で定義した「わくわく感」の定義に基 づいてD.S ンンテンツを作成し、実験協力者の

「わくわく感」と覚醒度を評価した。実験の結果、 脳波の $\beta / \alpha$ の平均值および心電のSDNNとRRVの 解析結果から、「サビ開始後」のわくわく感が

「サビ開始前」よりも大きい有意傾向を示した。 また、眼球運動データの単位時間当たりの瞬目回 数の解析結果から、音楽提示後に覚醒水準が上 がったと考えられる。以上の結果から、音楽提示 のサビ部分で「わくわく感」が大きくなり、その 後の覚醒水準が上がる可能性が示唆された。ただ し、これらの結果は音楽提示区間の1回目のみで 得られたため、さらなる検証が必要である。今後 は、自動運転時の覚醒水準低下防止が課題となる。

\section{参考文献}

1）西村：“ドライバーの覚醒水準と安全”，国際 交通安全学会誌，No. 19, pp. 19-28, 1993.

2) 原田他：“車載機器の感性評価の研究（第5 報)”，自動車技術会2014年秋季大会学術講演 前刷集，Vol. 119，No. 14，pp. 9-12， 2014.

3）橋本他：“誘発脳波からみた交通騒音の人体 に与える影響に関する研究”, 日本建築学会 環境系論文集，No. 570，pp. 1-6， 2003.

4）内藤他：“瞬目群発と単独瞬目を用いたリア ルタイム居眠り検出法の開発”, 信学技報, Vol. 113, No. 61, MBE2013-1, pp. 1-5, 2013. 